DOI: $10.1515 /$ hssr -2016-0026

\title{
The "Christian Spirit" of Capitalism and the Protestant Reformation, between Structuralist Analysis and Historical Evidence
}

Aurelian-Petruș Plopeanu*

Alexandru Ioan Cuza University of Iasi, Romania

\begin{abstract}
For many reasons, it is true that the Protestant Reformation unleashed the forces that lay behind the emergence of capitalism. Such a system was compatible with the emancipation of individuals, their mentalities, due to specific societal reforms and transformations. Therefore, it gave birth, in an unprecedented way, to a "new form of capitalism". But the main idea I want to stress in this article is that the capitalist ethos was present before the Reformation, many centuries ago, in what is called now the "Christian spirit". In this direction, I emphasize many theories which disagree with the Weber's well-known thesis about the relation between capitalism and religion, especially when it comes to generalize a particular result that is both theologically vague and empirically disprovable.
\end{abstract}

Keywords

Capitalism, Institutions, “Christian spirit”, Religion

\section{Introduction}

In medieval times, especially in the German territories, Catholicism suffered from a lack of theological clarity, which caused the general existence of a strong sense of anxiety and doubt among believers. A large

* Department of Interdisciplinary Research - Humanities and Social Sciences, Alexandru Ioan Cuza University of Iasi, Corpul Lascăr Catargi, Strada Lascăr Catargi 54, Iași 700107; aplopeanu@gmail.com 
number of scholastic schools of thought have emerged during the Middle Ages in response to the crisis triggered as early as the fifteenth century amid considerable confusion, even on the eve of the outbreak of the Reformation (McGrath, 1993: 9-28). In addition, the same state of confusion floated even over the "system" of salvation (Pelikan, 1984: 1058; Ozment, 1980: 22-42).

The status of the medieval Church in the German states is a special model to understand the starting point of the Reformation. In those times, there were many critical voices towards the institution of religion and its clergy. For example, the Church was considered a body lacking national leadership, a fact which would have caused the clergy to take advantage of such a deficiency and sometimes to neglect the welfare of their parishioners. Moreover, medieval religion had become a complex and contradictory system of belief. And yet, in medieval times, despite the declared weaknesses of the institution and of its servants, the salvation doctrine of a Roman Catholic origin continued to be the core of Christian faith. Few believers would think that salvation was possible without the intervention of the priest or that looking for divine truth could step beyond the realm of faith. On the contrary, there is strong evidence to suggest that the religious culture has never been less attached to the Church as it happened in the $15^{\text {th }}$ century. (Dixon, 2002: 42)

Reformation, with its internal incentives, made the unseen aspect of capitalism to fulfill according to a new state of order and this new spirit of capitalism put to the forefront the faith in reason, progress, the need of any individual to fulfill his or her vocation and duty to inherit God's empire. The result of the religious reforms of the $16^{\text {th }}$ century had a double meaning. First, the Church was integrated into the core state, its servants often carrying the same powers as the profane officials, leading the same institutions and being concerned with the same issues of power (discipline, public welfare, education, etc.). Secondly, the state became quasi-sacral, an interpreter and a defender of faith. The religious identity and secular rules began to merge, while the Church, in cooperation with the early modern state, started to purify, standardize and unify religious life. In this respect, Reinhard believed that such an action was an essential feature of the early modern era, specific of the formation of the national state which, despite clear differences in theology and liturgy between Catholicism and 
Protestantism, stood as the basis of Reformation and CounterReformation in the $16^{\text {th }}$ century (Dixon, 2002: 145).

However, the theology of the Reformation doctrine did not fill a doctrinal vacuum, but gained force and legitimacy only as a religious alternative (Dixon, 2002: 40-41). This new religious alternative was based primarily on the "pure materiality of the world" (lex naturae) (Patapievici, 2001: 98).

Thomas Brady said that, at least in the German states of the Middle Ages, "In an era of uncertainty, urban reform promised to convert civic religion from a disturbing force into one supporting and legitimizing the oligarchic authority and fundamental civic values" (Brady, 1988: 28).

When it comes to the discussion between Protestantism, Catholicism and economy, the debate is extremely complex and never definitely solved. The spirit of capitalism is inextricably linked to individual awareness of the idea of duty to wealth growth as a moral purpose. The link between material wealth maximization and the concept of vocation is determined by conditions of virtue, competence, skill and experience. Capitalist vocation, of ascetic-Protestant origin with carceral mark, has individual causes, related to the rational acquisition, by virtue, of personal ability and initiative (Barbalet, 2008: 75-76).

\section{The Core Ethos of Capitalism Pre-existed Protestant Reformation}

There are fervent polemics whether Weber's theory is fully truthful or not. Many voices have shown that the capitalist system has its roots in the $9^{\text {th }}$ and $12^{\text {th }}$ century, in the heyday of manorial manner of production and of feudal relations. In those days they produced to sell at a different profit, competition existed and manifested itself in pricing, private financing through credit operations, capital accumulation. The period of economic prosperity after bereavement (the War of 100 years and the "Black Death"), corresponding to the end of the $15^{\text {th }}$ century and the early $17^{\text {th }}$ century, rested on an economic architecture that began at the end of the $11^{\text {th }}$ century and extended until the beginning of the $13^{\text {th }}$ century (Berman, 2003: 163).

H.M. Robertson, Fanfani and Marshall showed that the characteristics that defined the Protestant ethic, through the concept of vocation, could 
be found in medieval Catholic philosophy (Barbalet, 2008: 104).

In contrast to Weberian theory and its advocates, Norman Tanner believed that the dominant medieval paradigm on the acceptance of sin was antagonistic to that of Calvinism. From such a change, the outlook on the world, the community, even on God takes on new fertile values. The Middle Ages followed the transition from the status of community to the status of individuals. After the Counter-Reformation, a response to the Protestant Reformation, the influence of the Semi-Pelagianism over the Roman Catholic theology and practice caused a change in an individual's relation to the soteriology of religion (Tanner, 2009: 177-178). Thus, through personal struggle and free will, one could attain salvation, which realistically transformed individual freedom into a vehicle of personal choice between good and evil.

Paul Münch highlighted the existence and internalization of moral codes of religious nature in everyday life that precede the onset of the Reformation. Already in the $14^{\text {th }}$ and $15^{\text {th }}$ century, a positive assessment of worldly activity could be seen by appealing to the spirit and rules of theology. Urban bourgeois society, linked to artisanal crafts and trade activities, started to develop business regulations and codes of commercial conduct. In this respect, a disciplinary process and the rationalization of human labor were initiated, a process that has been pushed forward until the end of the $18^{\text {th }}$ century. So, the fight against laziness and begging began in the late Middle Ages. In this case, the author considered that this perspective distorts the main hypothesis of Weber's thesis, that the appearance of the capitalist spirit should be seen as an indirect result of Protestant theology (von Greyerz, 2008: 220).

Herbert Luthy wondered why after the Counter-Reformation the conditions of the late Middle Ages Catholicism, which favored the emergence of Protestantism, cannot be found. Karl-Ludwig Ay believed that the capitalist spirit was not a result of the Reformation, but pre-existed this critical juncture of macro-history, being present already in the Renaissance, in humanism, in literature and medieval urban economy (von Greyerz, 2008: 220).

Two ideas belonging to Hartmut Lehmann are interesting to quote here in order to confirm the criticism of Max Weber's holistic theory: "On the one hand, it must be noted that forces of work ethic were being mobilized 
across all theological-confessional boundaries in seventeenth-century Christendom; both Protestant and Catholic authors saw in the difficult era in which they were living, in the faithful fulfillment of tasks within the world, a meaningful path of preparation for eternal salvation and a suitable means of achieving reconciliation with God. On the other hand, there is no denying that this mobilization could only take place and exert its influence within the framework of the political, social, and economic conditions of the various countries. Where the background conditions were favorable, as in England or the Netherlands, the more intensive, Christian occupational labor led to visible economic success, while in places where external conditions had a negative effect, as in France, Spain, and in many territories of the Old Empire, it produced no economic results worth mentioning. ... It was a fundamental mistake on Weber's part to deduce the theologicalethical motivation of Puritan business people from their external success, and then in turn to deduce the external success from this motivation" (von Greyerz, 2008: 223).

The American Catholic philosopher, Michael Novak, demonstrated, alongside Alan Macfarlane (1987), Jean Baechler, John A. Hall and Michael Mann (1988), Roy Porter and Mikulas Teich (1986) and Louis Baeck (1994), that the features that characterize any capitalist system and considered to be exclusively of Calvinistic origin - private ownership of the means of production, functional markets and the existence of profits - preexisted the moment of Reformation. So Novak's idea is that such economic behavior was common from ancient times, during the Old Testament, from Greek and Roman thinkers to scholastics. The wheel cannot be reinvented! Based on Arthur Mitzman's statement that Max Weber's father himself, being a Protestant, had a life conduct of a "Mediterranean" type, that is relaxed and oriented to enjoying the pleasures of life (Mitzman, 1970: 15-38), Michael Novak believed that the German sociologist's conjecture was subjected to various religious particularities inside confession, thus it cannot be generalized. For example, the city of Geneva, even a few generations after the death of Calvin, was not the favorable place to carry out banking activities which would have meant practicing interest and equity investments. In addition, a Protestant ethics cannot be recorded in the broad sense of the concept. Weber noticed some empirical evidence that allowed him to base his full thesis on it, but it 
would have been honest to specify that it is only about the Calvinist ethic, or rather a more marginal one, the Puritan ethic. Then, Novak showed that what defines Weber's Protestant ethic and the spirit of capitalism expresses a confusing anti-Christian anachronism, i.e. consistent and determined pursuit of the individual to enhance personal wealth or well-being as an aim in itself and not as a means or resource (Novak, 1993: 2-11).

H.R. Trevor-Roper considered that the Protestant theory may seem valid from some points of view. He agreed that Weber did not argue that capitalists never existed in the human history before the Reformation. The German scholar just spoke about a "new form of capitalism", created by a different human typology that was not stimulated by greed or primitive accumulation, but by "a moral discipline", the so-called "worldly asceticism", in search for the "calling". This "moral discipline" was the basis for the "rational bureaucratic capitalism" and the "rational organization of citizen labor", elements never before seen in history. Trevor-Roper concluded that, in some specific cases, the birth of a new spirit with Protestant roots represented the main factor to the formation of the modern industrial capitalism (Trevor-Roper, 2001: 5-6).

After emphasizing the main elements of Weber's theory, Trevor-Roper stressed the limits of such an approach and why it is wrong to generalize it easily. Its criticism particularly concerns the exceptions of the general theory, based on historical facts. For example, he emphasized the case of Calvinist Scotland, with important coal deposits, who did not record better economic development in comparison with England, dominated by a far worse Anglican system. He was surprised to find that Arminian Amsterdam represented the core space for the manifestation of the energies that created the economic boom in the United Provinces, while another province, the Calvinist Gelderland, was dominated by a social class which it was proven to be an enemy for progress (Trevor-Roper, 2001: 6). Other intriguing arguments regarded the case of many Calvinist business men who were not apologists of the "worldly asceticism", but rather they cultivated a plentiful and abundant life (Trevor-Roper, 2001: 19-20).

The main conclusion of Trevor-Roper was that such exceptions confirm the general rule that Calvinism could not be spread evenly, without taking into consideration the unpredictable and social, historic and cultural diversity. 
R. H. Tawney considered that capitalism preceded by many decades ago what was now considered the exclusive invention of Protestant Reformation. According to him, the Protestant Reformers' economic thinking did not seem so new and innovative. On the contrary, many elements were not sufficiently clear and made it medieval and even obsolete. For example, Luther condemned usury (interest), considering it a tool invented by the pope and the devil. In addition, he did not agree with international trade, monopolies or financial speculation. He militated to eliminate canon law, the Bible being sufficient to regulate all human actions. His intent was on maintaining the status quo of medieval social thought (Tawney, 1926: 54-56).

It is found that in Calvinism and other Puritan sects, the desire to win, as a goal in itself, did not have any ethical value, only salvation of the soul counted, the main focus of their discourse. This allowed making modifications of ethical principles that have shaped the economic and human action as a whole. Despite the rigor manifested, Calvinism has managed to attract many thinkers and liberal elite. Then, as Welzer or Rachfahl (Brăilean, Plopeanu and Chiper, 2011: 52) showed, Calvinist doctrine ingredients "led to a terrible request towards economic restriction (and political control) rather than the entrepreneurial activity that Weber had described" (Chalcraff and Harrington, 2001: 76).

Amintore Fanfani mentioned a new capitalist mentality present in Tuscany, Lombardy and Flanders during the $14^{\text {th }}$ and $15^{\text {th }}$ centuries. Its origin was established in the $14^{\text {th }}$ century in Florence, Flanders and the Hanseatic ports, as a secularized form of Christian activism in order to transform the social and economic life. This activism was guided by the Benedictine code: "Ora et labora" ("pray and work"), used by medieval monasticism and in the writings of Thomas d'Aquino. Fanfani disjoined Weber's thesis of creative minorities. He stressed that Huguenots and Dutch reformers in the $16^{\text {th }}$ and $17^{\text {th }}$ century forbade the application of interest in those activities based on excessive work because it reduced the time spent glorifying God. Also, the pursuit of profit at the expense of glorifying God was considered a sign of madness and damnation. Another finding that contradicts Max Weber's thesis was the Puritan idea of vocation, a Weberian ingredient that appeared very late in Western Europe, only in the $18^{\text {th }}$ century (Plopeanu, 2010: 223-334; Brăilean, Plopeanu and 
Chiper, 2011: 53-54).

Louis Baeck stressed interesting historical evidences for some Western territories. Therefore, more than four centuries before the Reformation, proto-capitalist institutions, actors and behaviors emerged with some intensity in northern Italy and Flanders. In this direction, it is important to quote these main ideas: "the emerging city-states of northern Italy and Flanders witnessed a population explosion, accompanied by an intense growth of trade and industry. In these urban growth centres the bourgeoisie was animated by an entrepreneurial spirit which initiated some form of proto-capitalism" (Baeck, 1994: 123). Besides these transformations in the social and economic realm, the religious reform (the Cluniac one) generated a new ethos for the Benedictine monks, based on an intrinsic equilibrium between religion and mundane manifestations. Hence, important effects on their accumulation of wealth (for example, rural estates) took place. The change of mentality for the Western man was, therefore, created, in the sense of a much more liberty for action (in praxeological sense). "With the twelfth century renaissance the prospects of Western man in the afterlife brightened and his enjoyment of material betterment improved as well. In the feudal mentality of the time it was assumed that a man's resources were a trust of which he was a steward rather than the owner. So long as the powerful and the wealthy spent lavishly on services, hospitality and charity or in social and cultural display, they stayed free from moral and religious disapproval and sanctions. Money and wealth were there to be spent, not to be hoarded or productively invested. The real sin was avarice, or worse still its companion, usury" (Baeck, 1994: 123-124). In this context, the economic role of the Cistercians was passed in the forefront, highlighting the great and unprecedented achievement. "In the stagnant rural economy of the age the radical breakthrough was the work of the Cistercians. This new order aimed at both spiritual austerity and rational exploitation of their domains. Animated by a complete sense of ascetic abnegation they fled the world and retired to the wilderness, where they pioneered rural development. Their estates were run with the managerial competence and the marketing strategies characteristic of modern agribusiness. In a relatively short time, hundreds of monasteries became incubators and vehicles of economic expansion" (Baeck, 1994: 124). 
More recently, Thomas Barnebeck Andersen, Jeanet Bentzen and CarlJohan Dalgaard (2013) challenged the Protestant origins of capitalism attributed to Max Weber. Rather, these researchers argue that the Weberian ethos had a pre-Reformation origin, based on a Cistercian source. As they consider, "the Cistercians encouraged growth by instigating the kind of cultural change that Weber attributed to Protestantism" (Andersen, Bentzen and Dalgaard, 2013: 2). Therefore, "This meant that within the walls of the Cistercian monasteries one would find cultural values similar to those which, promulgated by the Protestant Reformation centuries later, is thought to have assisted the rise of capitalism outside the monastic walls. ... Weber (1958: 118-119) himself singled out the Cistercians as encompassing values with a clear antecedent to the Protestant ethic" (Andersen, Bentzen and Dalgaard, 2013: 2).

For many reasons, the same authors emphasize the Cistercian origin for those values attributed by Weber to be the unseen inputs for capitalism: "First, a cultural concordance between the Cistercians and the Protestants in the dimensions of work ethics and thrift has already been observed by several scholars, including Weber himself. Second, the cultural explanation has the virtue of being able to account for the lingering Cistercian influence on growth. Third, consistent with the cultural mechanism, using data from the European Values Survey we find that Catholic regions in Europe, which historically were influenced relatively more by the Cistercians, tend to have populations with greater taste for hard work and, to a lesser extent, thrift today. These results carry over to England as well as to Europe more broadly. Fourth, given free mobility in the labor market, one would expect to see sub-regions with higher productivity to also feature higher employment rates. This suggests that regions that were "treated" by Cistercian monasteries historically should feature higher employment rates today, if indeed there is a lingering impact on productivity" (Andersen, Bentzen and Dalgaard, 2013: 30).

The final remarks state the idea stressed before: "the Cistercian order seems to have had a lasting impact on economic development in Europe. Overall, our research suggests that Weber was right in stressing the importance of a cultural appreciation of hard work and thrift but quite likely wrong in tracing the origins of these values to the Protestant reformation" (Andersen, Bentzen and Dalgaard, 2013: 30). 
Another recent research, developed by İ. Semih Akçomak, Dinand Webbink, Bas ter Weel (2013), establishes a strong connection between early Dutch economic development (since 1400) and the Brethren of the Common Life (BCL), a late 14th century religious movement founded to reform the Roman Catholic Church from inside. The main idea highlighted by their theory is that the Brethren of the Common Life "stimulated the accumulation of human capital among civilian people through vernacular (religious) texts, schools and the production of books. This increased the literacy rate of the Dutch population substantially. By 1600, literacy rates in the Netherlands were higher compared to surrounding regions. At the same time, economic activity was stimulated by this early literacy which led to a rise of economic development. Finally, the BCL followed a socially inclusive approach when educating citizens. They operated within the Roman Catholic Church, but emphasized people's own responsibility for making a living. Thus, the BCL laid the intellectual foundation for Christian Humanism, which is considered one of the most profound cultural changes in Western history. The early development and diffusion of Christian Humanism in the Netherlands provoked severe repression by the Habsburg rulers. This repression seems to be the most fundamental factor for the Dutch Revolt" (Akçomak, Webbink and ter Weel, 2013: 2).

The same authors proved the link between the Brethren of the Common Life and early Dutch human capital formation (book production, education) with important consequences for urbanization and economic development. "Overall our mechanism and empirical evidence shows that the BCL has been an important factor for the early development of the Netherlands. This research offers an explanation for why the Netherlands was the first country on the rise in the development of Europe by filling the time gap of about 200 years of European history" (Akçomak, Webbink and ter Weel, 2013: 36).

\section{Protestantism and the "Updated" Ethos of Capitalism}

Ernst Troeltsch wrote that, in reality, the goal of Weber's thesis was not just to highlight the capitalist spirit of the Calvinist idea of personal vocation (in the sense of legal profit obtained from capitalist economic activity), but also to explain the modern bourgeois lifestyle, in which "the capitalist spirit" was just a feature. In this regard, Troeltsch showed that 
Weber was concerned with modern features of the bourgeoisie and not with those that the modern capitalism has inherited from the ancient world and the late Middle Ages (Troeltsch, 1956: 894).

Weber and Troeltsch discovered the intimate side of a religion of feelings and belief, the Calvinist Protestantism type. Its specific type of individualism differed not only from the Catholic one and the Lutheran one, but also from the optimistic and rational individualism of the Enlightenment. Founded on a crushing sense of sin, it was an individualism based on the certainty of choice, a sense of responsibility and obligation to make a personal service under the reign of Christ. This found expression in the piety of Calvinist origin, deep, contemplative and conscious (Troeltsch, 1956: 589-590).

Although vague enough and questionable for different reasons, many advocates of the Weberian thesis believed that the Church's opposition to the profit and usury was a solid impediment to strengthen their belief in the Protestant origin of the spirit of capitalism. For example, Klassen remarked that, in the $16^{\text {th }}$ century, many Catholic business leaders became Protestants due to an exceptional tolerance of usury (Klassen, 2014: 68). Also, the perspective of Calvin (1509-1564) played an important role in this sense (Isaacs, 2006: 135). Another Calvinist, Claude Saumaise (1588-1653), had decisively prohibited usury from a theoretical point of view (Isaacs, 2006: 135).

These Weberian arguments cannot decisively circumvent the theories according to which Calvinism was the first "critical juncture" in terms of pro-usury economic thought, while the Catholic Church social theory represented the archaic defender of the prohibition. For instance, the Catholic Church carried out transactions involving loans with usury for the members of its clergy. In England, in the $13^{\text {th }}$ century, clerical taxes were so burdensome that clerics had to resort to recommended Italian usurers (Cahorsins) who demanded an annual interest rate of 60\%. Beginning with the $12^{\text {th }}$ century, monasteries became fully involved in numerous financial transactions involving usury (Wood, 2004: 171-173). But, in the $15^{\text {th }}$ century, the mainstream perspective on usury was against it. The only way that could circumvent the official regulations was when the fixed exchange rate between different currencies intervened between creditors and debtors. In this context, usury was easily camouflaged in the exchange rate 
mechanism (di Vittorio, 2006: 6).

Another refutable idea concerns the role of trade in shaping the capitalist ethos by Calvinism.

Henri Pirenne wrote that, although the pace of development of capitalism in the $12^{\text {th }}$ century can be compared with that of the Industrial Revolution in the early $19^{\text {th }}$ century, the Church's attitude towards trade manifested rather as hostile, for the merchant being hard or almost impossible to be able to fully thank God. In his view, there was, therefore, a strong doctrinal obstacle to validate the theory of the birth of the capitalist spirit (spiritus capitalisticus) before the Reformation (Berman, 1983: 336). The economic status of the Jewish traders was a strong proof that the Catholic Church was a doctrinal obstacle towards trade and investment (Pejovich, 1990: 8).

Harold Berman believed that the anti-commercial Catholic philosophy was actually a reflection of the economic position of the Church as a large landowner and property owner and identification with a conservative agrarian civilization. According to him, the Catholic Church has not applied systematically and vigorously the doctrine of sentence for achieving excessive profit simply because it had a special interest for a lax moral to practice their own commercial activities and not only (Berman, 1983: 336).

I consider such theories about trade refutable because of many reasons. During the Middle Ages, within the Catholic Church, the attitude towards trade suffered important mutations. If the Council of Rome (1078) held that traders were put up against the wall like some of the fiercest sinners and advised to change their activity, by the end of the $12^{\text {th }}$ century, the perspective was different. In 1199, Pope Innocent III (1161 - 1216) even canonized a true merchant from Cremona, whose name was Homobonus of Cremona (? - 1197). Moreover, an Italian company worked since 1253 under the motto "in the name of God and profit". Only during the early Renaissance, the merchant, seen as a stimulating agent for the social welfare, begun to claim his place in the gallery of the most virtuous actors within society (Wood, 2004: 116-119).

Peter Hersch awarded the concept of "intentional backwardness" with the value of a prime cause for the difference between some Catholic spreading areas and the superiority of Protestant ones (von Greyerz, 2008: 221). For example, an insight into the temporal evolution of attitudes and 
mentalities could explain the decay of trade and the financial sector in $17^{\text {th }}$ century Italy, not from an economic point of view, but from the perspective of a "loss of the commercial spirit" and "land rent mentality" (von Greyerz, 2008: 221).

\section{Conclusion}

Although the Catholic Church lost its medieval power, it continued to remain influent and decisive in many people's lives in the early modern period. The example of the German principalities demonstrates that the Reformation did not elude de facto the Catholic influence in societies. Although they were the richest in Europe, the German states adopted the Protestant dogma, especially Lutheranism, but without a definitive rupture from the old order. This fact stresses that Protestantism promoted only "pure materiality of the world" (lex naturae), but everything that could help to strengthen and enrich the new capitalist institutions for a new world paradigm it was taken into consideration.

The capitalist structure and mentality were already present in what is called the "Christian spirit", a construct never seen before in the human history. The "Christian spirit" was invented during the first Council of Nicaea in 325 AD. Many examples demonstrate that the seen elements of capitalism pre-existed the appearance and manifestation of the Protestant Reformation. But a trigger might have sparked in order to make capitalism sustainable and uniformly spread. Protestantism made possible an "updated" version of capitalism. The Reformation, with its individual and internal incentives, made the unseen aspect of capitalism to fulfill according to a new state of order based on freedom of conscience and political transformation. This "new spirit of capitalism" or the unseen part of it put to the forefront faith in reason, progress, any individual's need to fulfill its vocation and duty to inherit God's empire. Also, the new individual needed to break away from the chains imposed during the Middle Ages.

Although the previous idea seems clear and definitive, it is difficult to state it as an immutable truth. Let us not forget that the original and fundamental elements were already there! The argumentative context needed specific transformations to become a new one according to the innovative mentalities of emancipated individuals. 


\section{References}

Akçomak, I. S., D. Webbink, B. ter Weel. (2013). Why Did the Netherlands Develop so Early? The Legacy of the Brethren of the Common Life. IZA Discussion Paper No. 7167. available at http:/ / ftp.iza.org/dp7167.pdf.

Andersen, T. B., J. Bentzen, C.-J. Dalgaard. (2013). Pre-Reformation Roots of the Protestant Ethic, Working Paper Series no. 137, Centre for Competitive Advantage in the Global Economy, Department of Economics, The University of Warwick, 2013, p. 2, available at http://www2.warwick.ac.uk/fac/soc/economics/research/centres/cage/man age/publications/137_2013_andersen.pdf.

Baechler, J., J. A. Hall, M. Mann. (1988). Europe and the Rise of Capitalism. Oxford: Basil Blackwell.

Baeck, L. (1994). The Mediterranean Tradition in Economic Thought. London: Routledge.

Barbalet, J. (2008). Weber, Passion and Profits. The Protestant Ethic and the Spirit of Capitalism in Context. New York: Cambridge University Press.

Berman, H. (2003). Law and Revolution, II: The Impact of the Protestant Reformations on the Western Legal Tradition. Cambridge, Mass.: The Belknap Press of Harvard University Press.

Blickle, P. (1992). Communal Reformation. The Quest for Salvation in Sixteenth-Century Germany. London: Humanities Press.

Brady, T. A. (1988). In Search of the Godly City: The Domestication of Religion in the German Urban Reformation. in R. Po-Chia Hsia (ed.). The German People and the Reformation. Ithaca, NY: Cornell University Press.

Brăilean, T., A.-P. Plopeanu, Sorina Chiper (2011). Critical Perspectives on Weberian Ethics. European Journal of Science and Theology. Vol. 7. No. 4.

Chalcraff, D., A. Harrington. (2001). The Protestant Ethic Debate: Max Weber's Replies to his Critics, 1907-1910. Liverpool: Liverpool University Press.

di Vittorio, A. (2006). An Economic History of Europe. From Expansion to Development. London: Routledge.

Dixon, C. S. (2002). The Reformation in Germany, Oxford: Blackwell Publishers.

Fanfani, A. (2003). Catholicism, Protestantism and Capitalism. Norfolk: IHS Press.

Gregg, S. (2014). Did the Protestant Work Ethic Create Capitalism?,

MERCATORNET, 21 January 2014, accessed at

http://www.mercatornet.com/articles/view/did_the_protestant_work_ethic_ create_capitalism/13424.

Isaacs, M. D. (2006). Centennial Rumination on Max Weber's The Protestant Ethic and The Spirit of Capitalism. Boca Raton, Florida: Dissertation.com. 
HSS, vol. V, no. 3 (2016): 117-132

Klassen, M. L. (2014). Jesus Consumer. Reframing the Debate between Faith and Consumption. Lanham: University Press of America.

Macfarlane, A. (1987). The Culture of Capitalism. Oxford: Basil Blackwell.

Marshall, G. (1982). In Search of the Spirit of Capitalism, New York: Columbia University Press.

McGrath, A. E. (1993). Reformation Thought. An Introduction. Oxford: Blackwell.

Mitzman, A. (1970). The Iron Cage: An Historical Interpretation of Max Weber. New York: Knopf.

Moeller, B. (1972). Imperial Cities and the Reformation: Three Essays. Durham: Labyrinth Press.

Novak, M. (1993). The Catholic Ethic and the Spirit of Capitalism. New York: The Free Press.

Ozment, S. (1980). The Age of Reform 1250-1550. London: Yale University Press.

Patapievici, H-R. (2001). Omul recent: o critică a modernității din perspectiva întrebării "Ce se pierde când ceva se câstigăa?" (The Recent Man: A Critique of Modernity from the Perspective of the Question "What is Lost when Something is Won?"). Bucharest: Humanitas.

Pejovich, S. (1990). The Economics of Property Rights: Towards a Theory of Comparative Systems. Dordrecht: Kluwer Academic Publishers.

Pelikan, J. (1984). The Reformation of Church and Dogma (1300-1700). Chicago: University of Chicago Press.

Plopeanu, A.-P. (2015). An Endogenous Theory about the Role of Christianity in the Emergence of the Industrial Revolution, in Camelia Grădinaru, Roxana Patraș, Andreea Mironescu, Anca-Diana Bibiri, E. G. (ed.), From Manuscript to EBook, Iași: Alexandru Ioan Cuza University Publishing House.

Plopeanu, A.-P. (2010). Determinante religioase ale dezvoltării economice (The Religious Determinants of the Economic Development). Iași: Junimea.

Porter, R., M. Teich. (1986). Revolution in History. New York: Cambridge University Press.

Robertson, H. M. (1933). Aspects of the Rise of Economic Individualism. Clifton, N.J.: Kelley.

Tanner, N. (2009). The Ages of Faith. Popular Religion in Late Medieval England and Western Europe. London: I. B. Tauris \& Co. Ltd.

Tawney, R. H. (1926). Religion and the Rise of Capitalism. A Mentor Book.

Tillich, P. (1972). A History of Christian Thought: from its Judaic and Hellenistic Origins to Existentialism. New York: Touchstone.

Trevor-Roper, H. (2001). The Crisis of the Seventeenth Century: Religion, the Reformation and Social Change. Indianapolis: Liberty Fund. 
Troeltsch, E. (1956). The Social Teaching of the Christian Churches, London: Allen and Unwin, vol. II.

Viner, J. (1978). Religious Thought and Economic Society. Durham: Duke University Press.

von Greyerz, K. (2008). Religion and Culture in Early Modern Europe, 1500-1800. New York: Oxford University Press.

Weber, M. (2007). The Protestant Ethic and the Spirit of Capitalism. Bucharest: Humanitas.

Weber, M. (1958). The Protestant Ethic and the Spirit of Capitalism. New York: Charles Scribner's Sons.

Wood, D. (2004). Medieval Economic Thought. Cambridge: Cambridge University Press.

\section{Biographical note}

Aurelian-Petrus Plopeanu (b. 1982) is currently a PhD Researcher (CS III) in the Department of Interdisciplinary Research - Humanities and Social Sciences from "Alexandru Ioan Cuza" University of Iasi and an associate teaching assistant at the Faculty of Economics and Business Administration (FEAA). He has published several books: as a single author, The Religious Determinants of Economic Development (Junimea, Iasi, 2010), as a co-author, Political Economy (Institutul European, Iasi, 2012) and Economic Policy (Institutul European, Iasi, 2014). Since 2015, he has been a member of Workgroup for Empiric Research of Religion (AGER) within University of Bern, Switzerland. 